\title{
MINAT BACA SASTRA MAHASISWA S-1 PROGRAM STUDI PENDIDIKAN BAHASA DAN SASTRA INDONESIA FKIP UNIVERSITAS BENGKULU TAHUN PELAJARAN 2016
}

\author{
Novita Ferli Efendi ${ }^{1}$, Gumono ${ }^{2}$, dan M. Arifin ${ }^{3}$ \\ ${ }^{1,2,3}$ Program Studi Pendidikan Bahasa dan Sastra Indonesia \\ Jurusan Pendidikan Bahasa dan Seni \\ FKIP Universitas Bengkulu \\ novitaferli93@yahoo.com
}

\begin{abstract}
Abstrak
Tujuan penelitian ini untuk mengetahui minat baca sastra mahasiswa S-1 Program Studi Pendidikan Bahasa dan Sastra Indonesia FKIP Universitas Bengkulu Tahun Pelajaran 2016. Penelitian ini menggunakan metode deskriptif dengan pendekatan kuantitatif. Populasi dalam penelitian ini mahasiswa S-1 Program Studi Pendidikan Bahasa dan Sastra Indonesia FKIP Universitas Bengkulu Tahun Pelajaran 2016 dari Prodi Pendidikan Bahasa dan Sastra Indonesia berjumlah 318 orang. Sedangkan sampel penelitian ini menggunakan teknik random sampling sebanyak 80 mahasiswa semester $5 \mathrm{~A}$ dan $5 \mathrm{~B}$. Teknik pengumpulan data menggunakan angket dan wawancara. Minat baca sastra mahasiswa S-1 Program Studi Pendidikan Bahasa dan Sastra Indonesia FKIP Universitas Bengkulu Tahun Pelajaran 2016 akan dinilai dari empat aspek, yaitu perasaan ingin tahu mahasiswa, perhatian mahasiswa, keterlibatan mahasiswa, dan ketertarikan mahasisw. Teknik analisi data yang dilakukan dalam penelitian ini yaitu, tahap persiapan, tahap pelaksanaan, dan tahap pelaporan. Hasil penelitian ini menunjukan bahwa minat baca sastra mahasiswa S-1 Program Studi Pendidikan Bahasa dan Sastra Indonesia FKIP Universitas Bengkulu Tahun Pelajaran 2016 masih kurang (rendah). Adapun hasil dilihat dari keempat aspek, berdasarkan aspek perasaan ingin tahu mahasiswa diperoleh rata-rata 1,45 (kategori tidak baik), aspek perhatian mahasiswa diperoleh rata-rata 1,05 (kategori tidak baik), aspek keterlibatan mahasiswa diperoleh rata-rata 1,65 (kategori tidak baik), dan aspek ketertarikan mahasiswa diperoleh rata-rata 0,65 (kategori tidak baik). Berdasarkan hasil angket yang telah disebarkan (berjumlah 50) maka dari rata-rata angket menunjukan 1,8 (kategori kurang baik) menyatakan bahwa minat baca sastra mahasiswa dikategorikan masih kurang. Berdasarkan wawancara yang telah penulis lakukan, terdapat beberapa jawaban dari mahasiswa yang menyatakan bahwa minat baca sastra mahasiswa masih kurang. Hal ini diperoleh dari jawaban responden yang menyatakan kadang-kadang membaca karya sastra.
\end{abstract}

Kata Kunci: Minat Baca Sastra, mahasiswa.

\begin{abstract}
The purpose of this study is to determine the interest of literature reading for students of the study program of language and literature indonesian FKIP university of bengkulu 2016 school years. This Research uses descriptive approach. The population in this study are S-1 students of indonesian language and literature education program of FKIP university of bengkulu in the 2016 academic year of the indonesian language and literature education program are 318 people. While the sample of this study using random sampling teachique as much as 80 students five A ang five B semesters. Data collection teachique used
\end{abstract}


questionaises and interviews. Interest in reading literature students S-1 program of education of language and literature indonesian FKIP university of bengkulu in the 2016 school year it will be assessed from four aspects, that is curiosity students, student attention, studentinvolvement and interest. Data analysis techniques conducted in this research are preparatory phase, implementation stage and reporting stage. The result of this study indicate that the interest of literature reading for undergraduate students of the linguistic and letters education program of indonesian FKIP university of bengkulu in the academic year 2016 is still low (low). The result seen from the four aspects, based on the aspects of students curiosity obtained an average of 1.45 (not good category), aspects of students attention obtained and average of 1.05 (not good category), student engagement aspects obtained an average of 1.65 (not good category), and student interest aspects obtained an average of 0.65 (not good category). Based on the result of questionnaires that have been distributed (amounted to 50 ) then the average questionare showed 1.8 (less good category) states that interest in reading categorized students are still lacking. Based on the interviews that the authors do, there are some answers from students who stated that the interest in reading literature of students is still lacking. This is derived from respondent's answers that states sometimes read literary works.

\section{Keywords: Literature reading interest, students.}

\section{PENDAHULUAN}

Keterampilan membaca merupakan kunci keberhasilan belajar. Keterampilan membaca berperan penting dalam pengembangan diri secara berkelanjutan. Membaca merupakan perbuatan yang dilakukan berdasarkan kerja sama beberapa keterampilan,yakni mengamati,memahami,dan memikirkan (Tarigan, 1979:20).

Minat yaitu seberapa besar individu merasa suka atau tidak suka kepada suatu ransangan. Semua yang diminati akan lebih menarik perhatian. Adapun pengembangan minat dapat diartikan seagai rasa senang atau tidak senang dalam menghadapi suatu objek. Prinsip dasarnya adalah bahwa motivasi seseorang cenderung akan meningkat apabila yang bersangkutan memiliki minat yang besar dalam melakukan tindakannya. Dalam hubungan ini motivasi dapat dilakukan dengan jalan menimbulkan atau mengembangkan minat seseorang dalam melakukan tindakantindakannya. Misalnya dalam dunia kepemimpinan,para pimpinan diharapkan mampu menumbuhkan dan mengembangkan minat bawahan dalam melakukan tugas-tugasnya. Dengan demikian para bawahan akan memperoleh kepuasan unjuk kerja yang baik dan pada gilirannya dapat menumbuhkan motivasi kerja secara efektif dan produktif (Surya, 2013: 41-60).

Novel merupakan salah satu karya sastra yang bisa dibaca oleh mahasiswa tidak hanya dibaca sangat dikampus tetapi juga dapat dibaca dimana saja dan kapan saja. Novel adalah karangan prosa yang panjang mengandung rangkaian cerita kehidupan seseorang dengan orang disekelilingnya dengan menonjolkan watak dan sifat setiap pelaku. Buku merupakan bagian yang tidak dapat dipisahkan dari belajar. Buku merupakan sumber pengetahuan. Hal yang sering kurang disadari oleh mahasiswa adalah bahwa memiliki buku lain sekali artinya dengan memiliki kertas bergambar huruf. Kurangnya minat memiliki buku maupun karya sastra seperti novel mungkin timbul 
karena anggapan bahwa dosen dan kuliah merupakan sumber pengetahuan utama.

Minat berpengaruh dalam proses pembacaan karya sastra pada mahasiswa adanya minat atau ketertarikan berlebih dari dalam diri untuk terus membaca karya sastra akan berpengaruh pada tingginya kemampuan mahasiswa dalam memahami karya sastra. Kemampuan pemahaman yang tinggi akan membantu mahasiswa meningkatkan kemampuan menanggapi atau meresepsi suatu karya sastra. Hal lain terkait dengan permasalahan minat membaca mahasiswa untuk membaca karya sastra seperti pantun, novel, cerpen, puisi dan karya sastra yang lain masih termasuk rendah. Perkembangan Sastra Indonesia dewasa ini demikian luas dan pesatnya,dengan bentuk yang beragam,baik tentang sastra indonesia maupun yang menyangkut sastra daerah, Semuanya perlu dikembangkan dan disebarluaskan. Hal ini diperlukan bila kita berkeinginan agar karya sastra berkembang pesat sehingga mampu menjalankan peranannya untuk memenuhi kebutuhan emosiaonal dan intelektual masyarakat pemiliknya dan sekaligus mengharapkan agar sastra nusantara diakui secara internasional.

Sastra juga merupakan kritik kehidupan yang bersandar pada hukumhukum kebenaran dan keindahan. Seperti telah dijelaskan pada uraian-uraian sebelumnya,sastra menjelma melalui media bahasa. Oleh karena itu, peran bahasa tidak bisa dianggap sepele. Meminjam istilah Slamet Mulyana (1964), sastra menggambarkan pengalaman jiwa dalam bentuk rangkaian kata (bahasa) yang indah. Oleh karena itu produk sastra selalu mengutamakan harmoni antara bentuk dan isi (Sumardjo, 1979:23).

\begin{tabular}{lrrr}
\multicolumn{2}{c}{ Menimbang } & arti & penting \\
keterampilan & membaca & dalam \\
pengembangan & diri & individu & dan \\
perkembangan dalam membaca & karya
\end{tabular}

sastra,diperlukan langkah strategis dan komprehensif untuk meningkatkan keterampilan dan minat baca sastra mahasiswa FKIP Universitas Bengkulu. Oleh karena itu,diperlukan data dasar dalam meningkatkan minat baca sastra mahasiswa untuk dasar perencanaan program. Penelitian ini dilakukan untuk meningkatkan minat baca sastra mahasiswa FKIP Universitas Bengkulu. Adapun penelitian mengenai minat baca mahasiswa oleh Gumono, 2016 dengan judul profil minat membaca mahasiswa FKIP Universitas Bengkulu. Menyimpulkan bahwa secara umum minat membaca mahasiswa FKIP termasuk dalam kategori rendah, hal ini ditunjukan dengan angka $79.20 \%$ mahasiswa menyatakan "kadangkadang" memiliki keinginan membaca. Jawaban kadang-kadang ini lebih jauh condong kurang memiliki minat membaca (Gumono, 2016:20).

Karena dalam membaca karya sastra pada umumnya mereka lebih menyukai bacaan yang mudah dimengerti seperti halnya komik-komik, cerpen yang suka muncul didalam majalah-majalah anak, puisi-puisi yang terdapat dalam buku pelajaran bahasa indonesia, dan novelnovel bertemakan percintaan yang pada saat ini sudah disenangi para remaja tersebut.

\section{METODE}

Metode yang digunakan dalam penelitian ini adalah metode deskriptif dengan pendekatan kuantitatif. Penelitian kuantitatif adalah penelitian yang menjawab permasalahan-permasalahan pengajaran bahasa dan sastra indonesia dengan pengukuran terhadap variabelvariabel objek yang diteliti guna menghasilkan simpulan yang dapat digeneralisasikan,lepas dari konteks waktu dan situasi (Susetyo, 2015:6).

Teknik pengumpulan data yangdigunakan pada penelitian ini adalah: 
1. Angket, 2. Wawancara. Angket adalah teknik pengumpulan data yang dilakukan dengan cara memberi seperangkat pertanyaan atau pernyataan tertulis kepada responden untuk dijawabnya. Angketmerupakan teknik pengumpulan data yang efisien bila peneliti tahu dengan pasti variabel yang akan diukur dan tahu apa yang bisa diharapkan dari responden (Sugiyono, 2014:142).

Untuk penelitian ini, penulis menggunakan metode alat yang disebut skala likert,yakni satu instrumen yang berisi pernyataan-pernyataan dan responden diminta untuk menyatakan sikap dan pendapatnya tentang pernyataan tersebut dengan memilih dari lima kemungkinan dalam skala berjenjang yakni setiap pilihan diberi bobot sebagai berikut, sangat suka bobotnya 5; suka bobotnya 4; sangat tidak berpendapat bobotnya 3; tidak suka bobotnya 2; sangat tidak suka bobotnya 1 (Sugiyono, 2014:93).

Penulis menggunakan teknik analisis data angket sebagai berikut: 1 . Tahap Persiapan, Peneliti mempersiapkan angket (berjumlah 50) yang akan disebarkan kepada mahasiswa S-1 Program Studi Pendidikan Bahasa dan Sastra Indonesia. 2. Tahap Pelaksanaan meliputi : a. Menyebarkan angket secara random kepada mahasiswa S-1 Program Studi Pendidikan Bahasa dan Sastra Indonesia FKIP Universitas Bengkulu Tahun Pelajaran 2016 yang terbagi kedalam 2 kelas yaitu kelas A dan B dari semester 5. b. Peneliti juga melakukan wawancara tidak terstruktur atau terbuka dengan 2 orang mahasiswa dari semester 5A dan 5B. c. Setelah pengisian angket, maka peneliti memeriksa jumlah kuesioner dan memeriksa kelengkapan jawaban responden. d. Melakukan tabulasi data yang telah diperoleh. e. Melakukan analisis data. f. Menyimpulkan hasil yang telah diperoleh dari analisis data. 3. Tahap
Pelaporan, hasil penelitian dilaporkan dalam bentuk tabel.

\section{HASIL DAN PEMBAHASAN}

Berdasarkan analisis data diperoleh angket yang terdiri dari 50 pernyataan dan disebarkan kepada seluruh mahasiswa S-1 Program Studi Pendidikan Bahasa dan Sastra Indonesia FKIP Universitas Bengkulu Tahun Ajaran 2016. Namun penulis hanya mengambil 80 mahasiswa dari semester $5 \mathrm{~A}$ dan 5B. Alasan penulis mengambil 80 mahasiswa dari semester $5 \mathrm{~A}$ dan $5 \mathrm{~B}$ yaitu untuk memudahkan perhitungan persentase dalam pengolahan data. Selanjutnya penulis mengumpulkan dan melakukan proses perhitungan data yang telah terkumpul dengan penyajian data dalam bentuk tabel untuk mempermudahkan dalam mempersentasikan data angka dengan menggunakan rumus :
$4,2-5,0=$ sangat baik
$3,4-4,1=$ baik
$2,6-3,3=$ cukup
$1,8-2,5=$ kurang baik
$1,0-1,7=$ tidak baik

\subsection{Minat Baca Sastra dari Aspek Perasaan Ingin Tahu Mahasiswa}

Berdasarkan hasil kuesioner dari mahasiswa yang telah disimpulkan oleh penulis bahwa jawaban yang ditemukan adalah:

\section{a. Mahasiswa Kurang Menyenangi Karya Sastra}

Mahasiswa kurang menyenangi karya sastra karena mereka menganggap karya sastra itu sulit dan membutuhkan pemahaman serta kemampuan yang lebih agar dapat mengerti dengan karya sastra. Mahasiswa kurang menyenangi karya sastra menyebabkan mahasiswa cenderung malas akan belajar sastra atau mengikuti pelajaran sastra dengan sungguh-sungguh. 
Dari hasil yang didapat bahwa hanya 29 mahasiswa yang menyatakan suka dengan karya sastra yang diperoleh dari rata-rata 1,45 (kategori tidak baik), dilihat pada tabel 17. Dari pernyataan tersebut dapat diketahui bahwa sebagian besar mahasiswa kurang menyenangi karya sastra. Sehingga masih sangat kurang minat baca sastra mahasiswa S-1 Program Studi Pendidikan Bahasa dan Sastra Indonesia FKIP Universitas Bengkulu Tahun Ajaran 2016.

\section{b. Mahasiswa Sulit Mengerjakan Tugas Karya Sastra}

Mahasiswa merasa kesulitan dalam mengerjakan tugas karya sastra yang diberikan oleh dosen, karena mahasiswa sendiri kurang mengerti dan kurang paham akan materi karya sastra. Materi sastra yang dianggap mahasiswa paling sulit dalam mengerjakan puisi, pantun, novel, cerpen dan drama. Karena mahasiswa mengalami kesulitan dalam memahami bahasa puisi, pantun, novel, cerpen maupun drama.

Dari hasil yang didapat dinyatakan bahwa hanya 25 mahasiswa yang menyatakan suka dengan karya sastrayang diperoleh dari rata-rata 1,25 (kategori tidak baik), dilihat pada tabel 19. Dari pernyataan tersebut dapat diketahui bahwa masih sangat kurang minat baca sastra mahasiswa S-1 Program Studi Pendidikan Bahasa dan Sastra Indonesia FKIP Universitas Bengkulu Tahun Ajaran 2016.

Sementara itu, berdasarkan hasil wawancara terhadap beberapa orang mahasiswa mengenai minat baca sastra ditemukan permasalahan sebagai berikut :

\section{a. Minat Mahasiswa Terhadap Karya Sastra Kurang}

Kurang berminatnya mahasiswa terhadap karya sastra merupakan suatu penghambat dalam mencapai tujuan pembelajaran yang diinginkan. Mahasiswa mau mengikuti pelajaran karya sastra dan ingin membaca karya sastra karena merupakan kewajiban yang harus mereka jalani sebagai pelajar. Kurangnya minat mahasiswa terhadap karya sastra karena mahasiswa kurang paham dan belum dapat menikmati karya sastra.

Dari hasil yang didapat bahwa hanya 33 mahasiswa yang menyatakan suka dengan karya sastra yang diperoleh dari rata-rata 1,65 (kategori tidak baik), dilihat pada tabel 11.Dari pernyataan tersebut dapat diketahui bahwa masih sangat kurang minat baca sastra mahasiswa S-1 Program Studi Pendidikan Bahasa dan Sastra Indonesia FKIP Universitas Bengkulu Tahun Ajaran 2016.

\section{b. Membaca Karya Sastra itu Susah}

Kurangnya minat mahasiswa untuk membaca karya sastra karena mahasiswa menganggap karya sastra itu susah baik dari segi bahasanya maupun pemahamannya. Apabila mahasiswa dari awal sudah menganggap bahwa membaca karya sastra itu susah, maka sampai akhirpun mahasiswa akan beranggapan sama.

Dari hasil yang didapat bahwa hanya 20 mahasiswa yang menyatakan suka dengan karya sastra yang diperoleh dari rata-rata 1,0 (kategori tidak baik), dilihat pada tabel 12. Dari pernyataan tersebut dapat diketahui bahwa masih sangat kurang minat baca sastra mahasiswa S-1 Program Studi Pendidikan Bahasa dan Sastra Indonesia FKIP Universitas Bengkulu Tahun Ajaran 2016.

\section{c. Kurang Paham dengan Karya Sastra}

Mahasiswa kurang paham dengan karya sastra sangat berpengaruh pada proses membaca karya sastra. Mahasiswa tidak dapat memahami atau menyerap karya sastra yang dibaca. Hal ini dapat 
berpengaruh pada hasil membaca yang akan dicapai.

Dari hasil yang didapat bahwa hanya 31 mahasiswa yang menyatakan suka dengan karya sastra yang diperoleh dari rata-rata 1,55 (kategori tidak baik), dilihat pada tabel 14. Dari pernyataan tersebut dapat diketahui bahwa masih sangat kurang minat baca sastra mahasiswa S-1 Program Studi Pendidikan Bahasa dan Sastra Indonesia FKIP Universitas Bengkulu Tahun Ajaran 2016.

\section{d. Membaca Pelajaran Bahasa Lebih Mudah}

Membaca buku-buku pelajaran bahasa lebih mudah dibandingkan dengan membaca karya sastra. Adanya anggapan mahasiswa bahwa membaca pelajaran bahasa lebih mudah dari pada membaca karya sastra menyebabkan mahasiswa cenderung malas untuk membaca karya sastra.

Dari hasil yang didapat bahwa hanya 21 mahasiswa yang menyatakan suka dengan karya sastra yang diperoleh dari rata-rata 1,05 (kategori tidak baik), dilihat pada tabel 21. Dari pernyataan tersebut dapat diketahui bahwa masih sangat kurang minat baca sastra mahasiswa S-1 Program Studi Pendidikan Bahasa dan Sastra Indonesia FKIP Universitas Bengkulu Tahun Ajaran 2016.

\subsection{Minat Baca Sastra dari Aspek Perhatian Mahasiswa}

Berdasarkan hasil kuesioner dari mahasiswa yang telah disimpulkan oleh penulis bahwa jawaban yang ditemukan adalah:

\section{a. Kurang Memperhatikan Penjelasan Dosen}

Kurangnya perhatian mahasiswa terhadap penjelasan dosen karena mahasiswa kurang mengerti dan mahasiswa kurang tertarik dengan karya sastra.

Hasil pengamatan dapat diketahui bahwa pada proses belajar mengajar mahasiswa kurang memperhatikan penjelasan dosen mengenai karya sastra. Hal ini disebabkan oleh keadaan kelas yang sedikit ribut, sebagian mahasiswa sibuk membaca sendiri, ada juga mahasiswa yang keluar masuk kelas, serta gangguan dari luar kelas dari mahasiswa yang tidak belajar, mengakibatkan perhatian mahsiswa tidak terfokus pada penjelasan dosen mengenai karya sastra.

Dari hasil yang didapat bahwa hanya 13 mahasiswa yang menyatakan sangat tidak berpendapat dengan karya sastra yang diperoleh dari rata-rata 1,05 (kategori tidak baik), dilihat pada tabel 28 . Dari pernyataan tersebut dapat diketahui bahwa masih sangat kurang minat baca sastra mahasiswa S-1 Program Studi Pendidikan Bahasa dan Sastra Indonesia FKIP Universitas Bengkulu Tahun Ajaran 2016.

\section{b. Kurang Mengerti yang Disampaikan Dosen}

Mahasiswa kurang mengerti apa yang telah disampaikan oleh dosen karena mahasiswa sendiri kurang paham dan kurang memperhatikan penjelasan yang diberikan oleh dosen. Keragaman kemampuan berpikir mahasiswa juga penghambat seorang dosen menjadikan mahasiswa paham dan mengerti cara membaca karya sastra secara keseluruhan.

Dari hasil yang didapat bahwa hanya 31 mahasiswa yang menyatakan suka dengan karya sastra yang diperoleh dari rata-rata 1,55 (kategori tidak baik), dilihat pada tabel 14. Dari pernyataan tersebut dapat diketahui bahwa masih sangat kurang minat baca sastra mahasiswa S-1 Program Studi Pendidikan Bahasa dan Sastra Indonesia FKIP Universitas Bengkulu Tahun Ajaran 2016. 


\section{c. Kurang Bersemangat untuk Membaca Karya Sastra}

Mahasiswa kurang bersemangat untuk membaca karya sastra karena kurang paham dengan karya sastra yang akan dibaca. Dalam membaca karya sastra mahasiswa tidak mempunyai semangat membaca maupun mempelajari karya sastra karena tidak suka dengan karya sastra itu sendiri.

Tetapi sebagian dari mahasiswa ada juga yang suka membaca karya sastra yang akan membuat mereka semangat dalam membaca karya sastra.

Dari hasil yang didapat bahwa hanya 24 mahasiswa yang menyatakan suka dengan karya sastra yang diperoleh dari rata-rata 1,2 (kategori tidak baik), dilihat pada tabel 49. Dari pernyataan tersebut dapat diketahui bahwa masih sangat kurang minat baca sastra mahasiswa S-1 Program Studi Pendidikan Bahasa dan Sastra Indonesia FKIP Universitas Bengkulu Tahun Ajaran 2016.

\subsection{Minat Baca Sastra dari Aspek Keterlibatan Mahasiswa \\ Berdasarkan hasil kuesioner dari} mahasiswa yang telah disimpulkan oleh penulis bahwa jawaban yang ditemukan adalah:

\section{a. Tidak Ada Inisiatif Mahasiswa untuk Membaca Karya Sastra}

Kurangnya inisiatif mahasiswa untuk membaca karya sastra dapat menyebabkan kurangnya minat baca sastra mahasiswa karena dari keinginan didalam hati mahasiswa itu sendiri akan dicapai suatu minat.

Apabila mahasiswa membaca karya sastra karena kewajiban saja maka minat baca mahasiswa itu sendiri menjadi kurang. Akan tetapi apabila mahasiswa itu mempunyai inisiatif untuk membaca karyakarya sastra tanpa ada unsur kewajiban maka akan diperoleh hasil minat baca sastra mahasiswa yang lebih baik.

Dari hasil yang didapat bahwa hanya 33 mahasiswa yang menyatakan suka dengan karya sastra yang diperoleh dari rata-rata 1,65 (kategori tidak baik), dilihat pada tabel 29. Dari pernyataan tersebut dapat diketahui bahwa sebagian besar mahasiswa lebih senang dengan pelajaran lain. Sehingga masih sangat kurang minat baca sastra mahasiswa S-1 Program Studi Pendidikan Bahasa dan Sastra Indonesia FKIP Universitas Bengkulu Tahun Ajaran 2016.

\section{b. Tidak Adanya Kesadaran Mahasiswa Untuk Membaca Sastra}

Kurangnya kesadaran dari dalam diri mahasiswa untuk membaca karya sastra akan menyebabkan kurangnya minat baca sastra mahasiswa.

Dalam hal ini kesadaran yang dimiliki oleh mahasiswa untuk membaca karya sastra masih rendah, mahasiswa akan membaca karya sastra apabila ada tugas dari dosen atau kewajiban untuk mengikuti perlombaan membaca karya-karya sastra.

Dari hasil yang didapat bahwa hanya 40 mahasiswa yang menyatakan suka dengan karya sastra yang diperoleh dari rata-rata 2,0 (kategori kurang baik), dilihat pada tabel 23. Dari pernyataan tersebut dapat diketahui bahwa sebagian besar mahasiswa membaca karya sastra ketika diberi tugas oleh dosen. Sehingga masih sangat kurang minat baca sastra mahasiswa S-1 Program Studi Pendidikan Bahasa dan Sastra Indonesia FKIP Universitas Bengkulu Tahun Ajaran 2016.

\subsection{Minat Baca Sastra dari Aspek Ketertarikan Mahasiswa \\ Berdasarkan hasil kuesioner dari mahasiswa yang telah disimpulkan oleh penulis bahwa jawaban yang ditemukan adalah :}




\section{a. Kurang Tertarik dalam Mempelajari Karya Sastra}

Kurangnya ketertarikan mahasiswa untuk membaca atau mempelajari karya sastra menyebabkan kurangnya minat baca mahasiswa. Ada mahasiswa yang tidak tertarik untuk membaca karya sastra karena bagi mereka membaca karya sastra itu sulit dan kurang dipahami. Tetapi sebagian dari mereka ada yang tertarik untuk membaca karya sastra sehingga menjadikan mereka suka dengan karya sastra.

Dari hasil yang didapat bahwa 26 mahasiswa yang menyatakan tidak suka dengan karya sastra yang diperoleh dari rata-rata 0,65 (kategori kurang baik), dilihat pada tabel 6. Dari pernyataan tersebut dapat diketahui bahwa hampir seluruh mahasiswa kurang tertarik untuk membaca karya sastra. Sehingga masih sangat kurang minat baca sastra mahasiswa S-1 Program Studi Pendidikan Bahasa dan Sastra Indonesia FKIP Universitas Bengkulu Tahun Ajaran 2016.

\section{b. Kurang memiliki suatu keinginan untuk membaca karya sastra}

Tidak adanya keinginan dari dalam diri mahasiswa untuk membaca karya sastra akan menyebabkan kurangnya minat baca sastra mahasiswa.

Hal ini dapat diketahui dari mahasiswa yang tidak ingin membaca karya sastra, mereka lebih senang membaca buku-buku lain dibandingkan membaca karya sastra. Maka dari itu minat baca sastra mahasiswa menjadi rendah.

Dari hasil yang didapat bahwa hanya 29 mahasiswa yang menyatakan suka dengan karya sastra yang diperoleh dari rata-rata 1,45 (kategori tidak baik), dilihat pada tabel 44. Dari pernyataan tersebut dapat diketahui bahwa sebagian besar mahasiswa kurang memiliki keinginan untuk membaca karya sastra. Sehingga masih sangat kurang minat baca sastra mahasiswa S-1 Program Studi Pendidikan Bahasa dan Sastra Indonesia FKIP Universitas Bengkulu Tahun Ajaran 2016.

\section{PENUTUP}

\section{Kesimpulan}

Berdasarkan hasil penelitian pada Bab IV, penulis menyimpulkan bahwa minat baca sastra mahasiswa S-1 Program Studi Pendidikan Bahasa dan Sastra Indonesia FKIP Universitas Bengkulu Tahun Ajaran 2016 adalah sebagai berikut :

1. Berdasarkan hasil angket yang telah disebarkan (berjumlah 50) maka dari rata-rata angket menunjukan 1,8 (kategori kurang baik) menyatakan bahwa minat baca sastra mahasiswa dikategorikan masih kurang.

2. Berdasarkan wawancara yang telah penulis lakukan, terdapat beberapa jawaban dari mahasiswa yang menyatakan bahwa minat baca sastra mahasiswa masih kurang. Hal ini diperoleh dari jawaban responden yang menyatakan kadang-kadang membaca karya sastra.

\section{Saran}

1. Perlunya bantuan dari dosen untuk memperlancar proses belajar dan memberikan latihan-latihan kepada mahasiswa serta memberikan bimbingan. Hal ini penting untuk dilakukan agar mahasiswa mau memahami karya sastra dan menumbuhkan rasa senang dalam mempelajari dan membaca karya sastra.

2. Mahasiswa diharapkan tidak hanya mendengarkan penjelasan dari dosen, tetapi hendaknya banyak membaca buku-buku yang berkaitan dengan karya sastra agar lebih mengerti apa yang dijelaskan oleh dosen.

3. Peran dosen Bahsa Indonesia dalam meningkatkan minat baca pada 
mahasiswa sangatlah penting. Maka dari itu, sangat disarankan kepada dosen untuk selalu memberikan arahan dan motivasi kepada mahasiswa agar mereka mempunyai kemauan yang tinggi untuk membaca khususnya membaca karya sastra.

\section{DAFTAR PUSTAKA}

Gumono. 2016. Profil minat baca mahasiswa FKIP Universitas Bengkulu.

Sugiyono. 2014. Metode Penelitian Kuantitatif. Bandung : ALFABETA, Cv.
Surya, Mohammad. 2013. Psikologi Guru Konsep dan Aplikasi. Bandung: ALFABETA, Cv.

Susetyo. 2015. Penelitian kuantitatif dan penelitian tindakan kelas pengajaran bahasa dan sastra indonesia.

Tarigan. 1979. Membaca sebagai Suatu Keterampilan Berbahasa. Angkasa Bandung.

Sumardjo, Jacob dan Saini. 1997. Apresiasi Kesusastraan. Jakarta: PT. Gramedia Pustaka Utama. 